\title{
British Journalism Review
}

http://bjr.sagepub.com/

Good behaviour can be taught

Tim Luckhurst and Lesley Phippen

British Journalism Review 2014 25: 56

DOI: $10.1177 / 0956474814526518$

The online version of this article can be found at:

http://bjr.sagepub.com/content/25/1/56.citation

\author{
Published by: \\ (9)SAGE \\ http://www.sagepublications.com
}

Additional services and information for British Journalism Review can be found at:

Email Alerts: http://bjr.sagepub.com/cgi/alerts

Subscriptions: http://bjr.sagepub.com/subscriptions

Reprints: http://www.sagepub.com/journalsReprints.nav

Permissions: http://www.sagepub.com/journalsPermissions.nav

>> Version of Record - Feb 27, 2014

What is This? 


\section{Good behaviour can be taught}

\section{Tim Luckburst and Lesley Pbippen}

The first step in improping standards of journalism is to put etbics at the beart of reporting, starting with courses at our unipersities

At the launch of the $B \mathcal{F} R$, despite having winced at too much execrable reporting, Geoffrey Goodman remained convinced that the best of British journalism would triumph. That it has not owes much to the increasingly obsessive desire to erect rules and bureaucratic structures where ethical conduct alone might deliver improved journalism.

Since Aneurin Bevan urged the 1946 Labour cabinet to create a Royal Commission on the Press on the bluntly undemocratic grounds that "newspapers have created a climate of opinion unfavourable to us", ideologues have repeated with mechanical frequency the error of believing that rules, either regulatory or legal, can tame bad newspapers. It is at best naïve: just as the Homicide Act has not eliminated murder, so laws against phone hacking and harassment did not eradicate these offences. They were criminal when they were committed; virtually everything Sir Brian Leveson investigated was already either illegal or actionable under civil law.

So, controversy about whether the work of professional journalists should be regulated by rules or principles is not remotely new. Indeed, the entrenched positions are boringly familiar: supporters of a rules-based approach believe rules prevent misunderstanding and protect the innocent. Their opponents object that this promotes a mechanistic approach that places too much emphasis on obedience, too little on judgment and, worst of all, requires the involvement of the state. Small wonder, then, that Leveson's recommendations did not meet with universal approval in the newspaper industry. 
Newspaper cultures that routinely generate outstanding journalism are not rules-based. The Guardian, Nem York Times, Spectator and Le Monde are governed, above all, by values. Their journalists understand that they are engaged in an ethical profession. They are committed to ideals of democracy, accountability and public service. They work in newsrooms where critical analysis, reflection and debate are encouraged not merely tolerated.

Of course, in a newspaper industry in which every title was wedded to fourth estate ideals, such cultures would be universal. Sadly, one need not endorse wholly Goodman's description of a "squalid, banal, lazy and cowardly" trade to acknowledge that British journalism is not so virtuous. We believe the absence of ethical education among journalists contributes to this problem.

Beyond Britain's local press - which committed none of the sins Leveson investigated - the systematic training of journalists is rare. Local and regional newspapers require trainees to obtain qualifications from the National Council for the Training of Journalists, but such standards are not universal. Elsewhere it remains possible for talented graduates to advance by complying with editorial policy, which may teach little more than the ability to spot a story that will appeal to readers' worst instincts.

Until Leveson reported, Goodman's moan that such laxity served only the interests of rapacious proprietors remained entirely credible. Now, despite the continuing absence of an agreed system of press regulation, journalism has changed utterly. To the financial misery caused by online media has been added public outrage at the cruelties perpetrated by titles that pursued profit via hacking and intrusion. To recover a little trust, professional journalism urgently requires new defences.

\section{An etbical dimension to learning}

Ethics are a potent weapon. Judiciously applied they turn principles into practice. And they are intensely practical; taught as part of a broad academic and professional education, the ethical approach offers guidance that remains appropriate in the infinitely variable circumstances that arise in real newsrooms. It helps journalists to behave well under pressure. It prevents mindless box-ticking and discourages the evasion which rulesbased systems always encourage. Ethics engage head and heart. Rules are too easily regarded as little more than an incentive not to get caught.

So, how does one teach ethics and what should journalists learn? The 
NCTJ's response to the Leveson report produced valuable guidance. Since September 2013, trainee journalists on NCTJ-accredited courses have found ethical values embedded in their learning. Ethical questions and dilemmas are integrated in the teaching of reporting, writing and media law. To the mandatory core skills that honest editors throughout the industry demand, students must now add an ethical dimension.

What should this foundation consist of? Sincere respect for the basic foundations described in the newspaper industry's Code of Practice is essential but not sufficient. In the University of Kent's Centre for Journalism we believe the answer lies in a broader definition of what professional journalists should know in order to serve the public interest in the 21 st century. We start with four core principles: accuracy, sincerity, hospitality and the responsibility to bear witness.

Accuracy and sincerity are straightforward liberal values. To do the "six or seven things news can do for democracy" Professor Michael Schudson identifies in his invaluable Why Democracies Need an Unlovable Press (Polity Press, 2008), journalists must make sure that what they say is not false and they must say what they actually believe. Hospitality is Professor Stephen Ward's brainchild. He describes it in Global Fournalism Etbics (McGill-Queen's University Press, 2010). It is best understood as a willingness to promote dialogue between cultures.

The responsibility to bear witness is Richard Sambrook's encapsulation of Allan Little's belief that eyewitness journalism is uniquely valuable because it has "the power to settle part of the argument, to close down propaganda, to challenge myth making". Any code embracing accuracy, sincerity and hospitality would be less valuable were this commitment to producing a reliable first draft omitted.

These values equip reporters with ideals with which to resist pressure to mislead or distort. Widely understood and appreciated they do more: they change hearts and minds. Journalists who have worked in newsrooms where ethical journalism is treasured have witnessed the reality. Professional practice is discussed. Colleagues care about what their readers, viewers or listeners might think not just of their story but of the methods used to acquire it. Collectively they stand up to editors who make unprincipled demands.

But basic ethics do not a principled journalist make. Such a skeleton foundation is but a starting point. To employ ethical tools effectively students must understand fully the purposes journalism exists to serve. 
And let us not ignore the value of enlightened self-interest. Journalism education must work for journalists, not just for the communities they inform, educate and entertain. This, fortunately, is the easy bit.

For as long as graduates have aspired to work in newsrooms students have questioned how best to secure a first job in journalism. Wellintentioned advice has tended to recommend a degree in history, politics or English literature followed by a graduate traineeship. Recently, universities offering degrees in journalism have made the case for learning core practical skills as an undergraduate in order to enter the marketplace with a competitive advantage.

\section{Good journalism serves to inform and civilise}

Modern demands mean these two strands must be combined. Ethical, professional journalists need to understand how representative democracy works, why it is precious and how good journalism serves to promote, inform and civilise it. To convey this wisdom we teach our students history, politics, law and literature. And we ensure that they study reports that plainly served the public interest.

Among our examples is Jay Allen's despatch for the Chicago Daily Tribune about the massacre by Franco's nationalist forces of Republican men, women and children at Badajoz in August 1936. It is an emotionally searing example in which accuracy and sincerity are propelled by courage and all three combine to hold power to account. Contemplation of George Steer's account of the bombing of Guernica for The Times - which in translation for L'Humanité inspired Picasso's modernist masterpiece - and Henry Buckley's meticulous accounts of the final Republican assault across the Ebro inform our study of journalism in the Spanish Civil War. It is a case study that reveals as much that is awful, dishonest and propagandist as it does about journalistic courage and integrity.

Next we introduce them to Peter Ritchie Calder's accounts for the Daily Herald of the Blitz in London's East End. Here there is no myth making, no united national family happily assembled beneath monarch and government to spout defiance at the Luftwaffe. Calder pinpoints the government's pitiful preparations to deal with the homelessness, hunger and misery brought about by bombing. "I have myself seen cases of psychological shock amongst the homeless as acute as surgical shock," he writes, addressing his words to a cabinet that preferred not to learn from a mass 
circulation newspaper that "Maginot lines of official obstructions" stood between the poor and the help they needed and that "official blundering" turned parts of the East End into "the tomb of whole families".

Calder and equally brave journalists on local London titles faced accusations of "giving comfort to the enemy" from the politicians of 1940. Their only offence was to use every ounce of professional skill and ethical commitment to turn the propaganda myth of a people's war into something a little closer to the reality. They succeeded as countless good reporters have since. Students who aspire to work as reporters should study their work. They should also study, among others, Ian Bell, Martha Gelhorn, James Cameron, Marie Colvin, Barbara Demick, Anne Leslie and Allan Little. No such list can be remotely comprehensive, but awareness of what truly great reporters have achieved should, surely, be as essential to the ethical education of a budding journalist as understanding human anatomy is to a student of medicine.

\section{Rules-based solutions bave failed}

Of course, ethics cannot guarantee virtue. Diversity and plurality of media ownership, and a newspaper regulator acceptable to the entire industry would be needed to promote ethical journalism education as a foundation for all reporting. Even then, Dr Pangloss would be disappointed because no system of journalism education in a democracy can make the press behave as Hacked Off might like it to. Democracy would be imperilled if it did. The difference between ethics and rules-based regulation is that the latter promises much and delivers little, whereas ethical education promises only to encourage thought and frequently spawns outstanding journalism.

Since the emergence of representative democracy in economically liberal nation states, journalists have promoted the notion that they work as servants of the public sphere, the realm in which citizens engage in critical debate about the practices of government and state. As actual standards have plunged towards trivialisation and vulgarity, even the most egregious offenders have continued to proclaim their determination to deploy the sword of truth and the shield of fairness. It is time to turn their empty rhetoric into real idealism. The teaching of ethics can help to make this possible.

If you doubt it, remind yourself that the search for rules-based solutions 
has failed repeatedly since the 1947 Royal Commission was charged with "furthering the free expression of opinion through the Press and the greatest practicable accuracy in the presentation of news..." Clement Attlee knew it would. He told that 1946 Cabinet meeting at which Bevan sought powers to create a more compliant press, "The more you expose evil, the more you will be pressed to produce your remedy. This means either a government newspaper or control which would be said to limit the freedom of the press". Ernest Bevin added a warning that any such interference would damage Britain's reputation abroad. His concerns about state-sanctioned regulation of newspapers remain vividly relevant today.

In 1989, Goodman observed that "anyone who thinks seriously about the state of the media must notice a great discrepancy between general statements and the actual world to which they are supposed to apply". Teaching ethics to a new generation of professional journalists can begin to close that gap. It will take time for such new recruits to dominate the industry, but the need for journalism that can speak truth to power and good enough to make power listen is real. And the internet's power to spread it far and wide at unprecedented speed makes such journalism additionally valuable.

The NCTJ is to be congratulated for strengthening its core professional syllabus with a principled and practical approach to ethics. It gives universities a fresh incentive to offer aspiring journalists a level of ethical and critical awareness that can enhance their careers and restore the profession's reputation. Ethics offer a realistic pathway to standards that regulation of the type Leveson proposed can never guarantee. They augment the rule of law with a dimension that requires reporters to think not about what they can get away with, but about what they ought to do. Ethics place the power to improve the profession in the hands of practitioners. Taught with passion and conviction they help to undermine any lingering delusion that regulation underpinned by charter or statute can improve reporting.

Tim Luckburst is head of the Centre for Fournalism at the University of Kent. Lesley Phippen is lecturer in law and director of graduate studies at the Centre. 